\title{
NEW SITES OF BRYORIA CAPILLARIS (ACH.) BRODO \& D. HAWKSW. (ASCOLICHENES, PARMELIACEAE) IN THE POLISH PART OF THE BIAŁOWIEŻA FOREST
}

\author{
Anna Matwiejuk, Adam Bohdan \\ A. Matwiejuk, Institute of Biology, University of Bialystok, Świerkowa 20 B, 15-950 Białystok, Poland, \\ e-mail: matwiej@uwb.edu.pl \\ A. Bohdan, Association “Workshop for All Beings”, Podlaskie Branch, Świętojańska 22/1, 15-082 Białystok, \\ Poland, e-mail: adam.bohdan@wp.pl
}

(Received: June 16, 2014. Accepted: July 31, 2014)

\begin{abstract}
AвSTRACT. The paper presents the results of the research on Bryoria capillaris (Ach.) Brodo \& D. Hawksw. in the Polish part of the Białowieża Forest. Two new sites of this species have been found in the managed Białowieża Forest, in Władysław Szafer Reserve. Bryoria capillaris grows on the bark and small branches of Quercus robur and Picea abies.
\end{abstract}

Key wORDs: threatened, lichens, Białowieża Forest, Władysław Szafer Reserve, NE Poland

\section{INTRODUCTION}

Białowieża Forest is an important centre of lichen biodiversity in Poland (CzyżEwsKa 2003). From the Polish part of the Białowieża Forest 450 lichen species have been reported (CIEŚLIŃSKI 2010). Many species are considered to be extinct in this part of the Polish Białowieża Forest and most of them belong to the Bryoria and Usnea genera (CZYŻEWSKA \& CIEŚLIŃSKI 2003).

Species of the genus Bryoria in Poland and Europe belong to the lichen most sensitive to changes in the environment and organisms, and are endangered. The most valuable, rare species is Bryoria capillaris (Ach.) Brodo \& D. Hawksw. This species grows in a natural, well-preserved forest complexes, on the bark of deciduous trees (Acer, Alnus, Betula, Fagus, Quercus, Sorbus, Tilia) and coniferous trees (Abies, Larix, Picea, Pinus), in lowlands and mountains (in submontane to subalpine belts, ca 600-1620 m alt.; Alstrup \& Olech 1992, FaŁtynowicz 2003, ZalewsKa 2012). In many countries this species is endangered (TÜRK \& HAFELLNER 1999, CIEŚLIŃSKI et al. 2006, LIŠKA et al. 2008, NASCIMBENE et al. 2012, Woods \& Coppins 2012).

The paper presents the new findings of Bryoria capillaris, in the managed part of Białowieska Forest, an epiphytic component of its biota.

\section{STUDY AREA}

The Białowieża Primeval Forest is a unique forest complex in Poland and Europe. Geographically it belongs to the Nizina Północnopodlaska (Północnopodlaska lowland) and the Równina Bielska (Bielska Plain). The Białowieża Forest is an important centre of lichen biodiversity in Poland (CZYŻEwsKa 2003). It is a forest complex covering the area of 150,000 ha located on the both sides of the Polish-Belorussian border. Western part, situated in Poland, covers the area of 62,500 ha; eastern part, situated in Belarus, covers the area of $87,500 \mathrm{ha}$. On the Polish side, the part of the Białowieża Forest is protected as the Białowieża National Park, with general area of 10,517.27 ha. The Białowieża National Park protects the best preserved fragment of Białowieża Forest - last natural forest at the European Lowland Area, having the primeval character. The characteristic feature of the park is its biological diversity.

The landscape reserve of Władysław Szafer was created in 1969 on 1,356.91 ha, along the main Hajnówka-Białowieża road. The protected belt of the forest is from 700 to 1,000 meters wide. It presents variety of plant communities with dominating Tilio carpinetum (www.encyklopedia.puszcza-bialowieska.eu). 


\section{MATERIAL AND METHODS}

The research on the lichen biota of the Białowieża Forest has been carried out since 2010. In the case of B. capillaris small fragments of the thallus were taken in order to analyse them in the laboratory. The herbarial material was deposited in the Herbarium Institute Biology (Białystok). The sites were localised with a GPS WGS 84 DD MM.MMM. The locations of sites were determined taking into account the national network of ATPOL. Identification of lichen acids was based on the standard methods described in literature (Culberson \& Ammann 1979, Orange et al. 2001). Chemical analyses were performed using thin-layer chromatography (ORANGE et al. 2001) with the use of solvents $\mathrm{A}$ and $\mathrm{C}$. The species has been named according to DieDERICH et al. (2014).

\section{RESULTS}

In 2010, in the Białowieża Forest, in the Białowieża District, in the Władysław Szafer Reserve two new stands were reported (squares GC 64 and GC 65 of the national network of ATPOL) of Bryoria capillaris. These are new stands in the Białowieża Forest and in north-eastern Poland. On new sites, the thallus of this lichens growing on the bark and small branches of Quercus robur and Picea abies in forest Tilio-Carpinetum.

\section{DIAGNOSTIC CHARACTERS}

Thallus was subpendent or pendent, to $30 \mathrm{~cm}$ long, whitish-grey, greyish-green or brownish grey, and dull. The branches were primarily even, however sometimes uneven and twisted, up to $30 \mathrm{~cm}$ long, slender, mostly $0.1-0.3 \mathrm{~mm}$ thick. The branching was isotomic dichotomous to anisotomic dichotomous with acute angles. The angles between the main branches were V-shaped. Soralia was mostly absent, but when present, it was tuberculate. Pseudocyphellae was present, and either linear or fusiform, 0.1-0.25 $\mathrm{mm}$ and apothecia was absent (see Holien 1989, WIRTH 1995, BRODO et al. 2001). Results of chemical analysis: alectorialic acid, barbatolic acid, \pm atranorin in the thallus, fumarprotocetraric acid in the soralia; thallus of $\mathrm{Pd}+$ yellow, $\mathrm{KC}+$ red, $\mathrm{C}+$ yellow-orange flesh, cortex and medula $\mathrm{Pd}+$ yellow, $\mathrm{K}+$ yellow, $\mathrm{KC}+$ red, $\mathrm{C}+$ pink, soralia $\mathrm{Pd}+$ orange-red.

\section{ECOLOGY AND DISTRIBUTION}

On new sites in the Białowieża Forest Bryoria capillaris was collected on Picea abies and Quercus robur in old, shaded forests Tilio-Carpinetum. Species belonging to the Bryoria genus, as well as numerous species from the Usnea genus, obviously prefer upper parts of trunks and tree-crowns in $2 / 3$ length of trunk. It is the natural habitat for this group of lichens. As compared with lower parts of trunks, lichens growing there have better access to light and higher relative air humidity thanks to transpiration from treeleaves. Associated species were Hypogymnia physodes, Parmelia sulcata, Platismatia glauca, Tuckermanopsis chlorophylla, Usnea filipendula.

The circumstances in which the species was found suggest that the number of its sites in the Białowieża Forest might be bigger, especially because it frequently occurs in the Białowieża National Park (GolubKov et al. 2012), where Bryoria capillaris were present on the dead or dying spruces (Picea abies).

The destribution of this species in Europe is well recognised and has been published by many authors (Seaward 1994, Kondratyuk et. al. 1996, MotieJŪNAITĖ 1999, VĚZda \& LišKa 1999, HafElLner \& TÜRK 2001, Llimona \& HLadun 2001, Coppins 2002, SøChtING \& Alstrup 2002, YazÝcÝ \& AsLan 2002, SANTESSON et al. 2004, LuKÁČ 2009, URBAnavichus \& AndREeV 2010). In Poland, B. capillaris was recorded mainly in the mountains and foothills (BYSTREK 1962, MоTYKA 1962, ТовоLewski 1965, KiszKa 1967 a, b, 1985, FABISZEWSKI 1968 b, ORdyCZyŃSKA 1973, NowAK \& ToBOLEWSKi 1975, Bystrek \& Cieśliński 1976, Alstrup \& Olech 1990, 1992, NowaK 1998, Śliwa 1998, BielczyK 2003, ŁUBEK 2004, CZARNota et al. 2005, SzCZEPAŃSKA 2006, 2008, SzczepańsKa \& SzCZEpański 2006, KossowsKA et al. 2007). It is rare in the lowlands (GLANC 1969, Rydzak \& SAŁATA 1970, Bystrek \& Bystrek 1972, WARMiŃSKa 1973, BYSTREK \& Ożóg 1974, BySTREK \& GórzyŃsKa 1977, Bystrek 1979, FAŁTYNOWicz 1992, KowalewSKA et al. 2000, ZalewSKA 2012).

In the Białowieża Forest it was recorded only a few times - RYDZAK $(1961,1969)$, as Bryoria (Alectoria) cana (Ach.) Leight. and B. setacea (Ach.) Brodo \& D. Hawksw.; FabiszewsKi (1968 a) as Bryoria (Alectoria) cana (Ach.) Leight.; BYstreK and Kolanko (1992), as Bryoria (Alectoria) capillaries (Ach.) Cromb., B. cana (Ach.) Leight. and B. setacea (Ach.) Brodo \& D. Hawksw. and SPARrius (2003).

\section{DISCUSSION}

Genus Bryoria causes taxonomic problems due to the morphological and chemical variability, and the few other diagnostic characters often present. The sect. Implexae is the most problematic, and is composed in Europe of lichens named Bryoria capillaris, $B$. chalybeiformis, B. fuscescens, B. glabra, B. implexa, B. lanestris, and B. subcana (BoludA et al. 2014). One of the characters used to separate the "species" have been the chemical products (extrolites), but their distribution can be patchy. Preliminary data of a phylogenetic analysis using the nuITS, nuLSU, mcm7, RPB1, and mtSSU regions suggest that: a) the European populations of sect. Implexae may best be considered as a single species; b) a single thallus can be composed 
of two or more distinct individuals; c) extrolites are heterogeneously distributed along the thallus and can be restricted to certain parts; and d) the chemotype identification by traditional reagent spot test can lead to errors (Boluda et al. 2014).

At present B. capillaris belongs to the CR (critically endangered) category in Poland (CIEśLIŃsKI et al. 2006), and locally (Białowieża Forest, the Świętokrzyski Mts, the Gorce Mts., Polish part of the Sudety Mts.) it is considered to be Regionally extinct (RE category; see Cieślíśsi \& ŁUBEK 2003, CZARnotA 2003, CZYŻEWSKA \& CieśLIŃSKI 2003, KossowSKA 2003).

For a long time during the intensive lichenological research carried out since the late 1980s B. capillaris was considered to be extinct in the Białowieża Forest (CIEŚLIŃsKi \& ToBolewsKi 1988, CieśliŃSKI 2003). Currently observed here are well developed and well-being of thallus B. capillaris (GolubKov et al. 2012).

Nowadays thallus of this species was recorded only on the bark of oak Quercus and spruce Picea in Białowieża Forest. Earlier, B. capillaris was reported from the bark of hornbeam Carpinus, maple Acer, spruce Picea, oak Quercus, birch Betula, pine Pinus (RYDZAK 1961, 1969) and from the bark of pine Pinus trees (SPARRIUS 2003).

In Central Slovakia (LuKÁč 2009) B. capillaris is a commonly found lichen in the valley. The variation in the chemical make-up of the species is high. The thallus did not contain only alectorialic acid, barbatolic acid, and \pm atranorin but also some specimens had other substances, which Holien (1989) designated as unknown acids.

Bryoria capillaris was specially considered due to its chorological and ecological implications within southern Europe region (ARAGón et al. 2006).

Specimens examined: GC 64 - Białowieża Forest, Władysław Szafer Reserve, branch 445 A, N $52^{\circ} 42.162^{\prime}$, E $23^{\circ} 43.081^{\prime}$, bark of Quercus robur, 25 August 2011, det. A. Bohdan, M. Popławska; GC 65 - Białowieża Forest, Władysław Szafer Reserve, branch 449 D, N 52 $41.852^{\prime}$, E $23^{\circ} 47.548^{\prime}$, bark of Picea abies, 18 July 2011, det. A. Bohdan, M. Popławska.

\section{ACKNOWLEDGEMENTS}

The authors would like to thank Marta Popławska for releasing the materials and data.

\section{REFERENCES}

Alstrup V., Olech M. (1990): Additions to the lichen flora of the Polish Tatra Mountains II. Zeszyty Naukowe Uniwersytetu Jagiellońskiego, Prace Botaniczne 21: 211-217.

Alstrup V., Olech M. (1992): Checklist of the lichens of the Tatra National Park, Poland. Zeszyty Naukowe Uniwersytetu Jagiellońskiego, Prace Botaniczne 24: 185-206.
Aragón G., Rico V. J., Belinchón R. (2006): Lichen diversity from Cazorla, Segura and Las Villas Biosphere Reserve (SE Spain). Nova Hedwigia 82, 1-2: 31-50.

BielczyK U. (2003): The lichens and allied fungi of the Polish Western Carpathians. In: U. Bielczyk (ed.). The lichens and allied fungi of the Polish Carpathians. An annotated checklist. Władysław Szafer Institute of Botany, Polish Academy of Sciences, Kraków, 23-232.

Boluda C.G., Rico V.J., Divakar P.K., Crespo A., Hawksworth D.L. (2014): Species concepts in Bryoria sect. Implexae (Parmeliaceae): is chemistry a sound diagnostic character? New developments in lichenology: systematics, ecology and use as indicators of environmental quality. Symposium abstracts. http://www.britishlichensociety.org. uk/sites/default/files/Abstractsbooklet_amend_ Charlesworth.pdf [access: 9.07.2014].

Brodo I.R., Sharnoff S.D., Sharnoff S. (2001): Lichens of North America. Yale University Press, New Haven CT.

Bystrek J. (1962): Studia nad florą porostów Tatr. I. Rodzaj Alectoria Ach. w Tatrach polskich. Fragmenta Floristica Geobotanica 8(2): 191-204.

Bystrek J. (1979): Porosty rezerwatu Obrocz w Roztoczańskim Parku Narodowym. Annales Universitatis Mariae Curie-Skłodowska, Sectio C, 34, 2: 9-24.

Bystrek J., Bystrek J. (1972): Materiały do flory porostów okolic Suśca na Roztoczu Środkowym. Annales Universitatis Mariae Curie-Skłodowska, Sectio C, 27, 16: 169-183.

Bystrek J., CieśLIŃski S. (1976): Gatunki rodzaju Bryopogon Link. emend. Bystr. na obszarze Gór Świętokrzyskich i ich pobrzeży. Fragmenta Floristica Geobotanica 22, 4: 553-557.

Bystrek J., Górzyńska K. (1977): Porosty Pojezierza Łęczyńsko-Włodawskiego. Annales Universitatis Mariae Curie-Skłodowska, Sectio C, 32, 3: 53-68.

Bystrek J., Kolanko K. (1992): Effect of anthropopressure on epiphytic flora of lichen as exemplified by the Białowieża Primeval Forest. Annales Universitatis Mariae Curie-Skłodowska, Sectio C, 47: 125-132.

Bystrek J., Ożóg K. (1974): Materiały do flory porostów okolic Krasnobrodu na Roztoczu Środkowym. Fragmenta Floristica Geobotanica 20, 2: 259-270.

CieśLIŃsKi S. (2003): Atlas rozmieszczenia porostów (Lichenes) w Polsce północno-wschodniej. Phytocoenosis 15 (N.S.), Suppl. Cartographiae Geobotanicae 15.

CIEŚLIŃSKI S. (2010): Wykaz gatunków porostów (grzybów zlichenizowanych) Puszczy Białowieskiej (NE Polska). Parki Narodowe i Rezerwaty Przyrody 29, 2: 3-39. 
Cieśliński S., CZyŻEwska K., FABISZEwski J. (2006): Red list of the Lichenes in Poland. In: Z. Mirek, K. Zarzycki, W. Wojewoda, Z. Szeląg (eds). Red list of plants and fungi in Poland. W. Szafer Institute of Biology, Polish Academy of Sciences, Kraków, 71-90.

Cieśliński S., ŁubeK A. (2003): Czerwona lista porostów zagrożonych w Górach Świętokrzyskich In: K. Czyżewska (ed.). Zagrożenie porostów w Polsce. Monographiae Botanicae 91: 143-158.

Cieśliński S., Tobolewski Z. (1988): Porosty (Lichenes) Puszczy Białowieskiej i jej zachodniego przedpola. Phytocoenosis 1 (N.S.), Suppl. Cartographiae Geobotanicae 1.

Coppins B.J. (2002): Checklist of lichens of Great Britain and Ireland. British Lichen Society, Huddersfield.

Culberson C.F., Ammann K. (1979): Standardmethode zur Dünnschichtchromatographie von Flechtensubstanzen. Herzogia 5: 1-24.

Czarnota P. (2003): Czerwona lista porostów zagrożonych w Gorcach In: K. Czyżewska (ed.). Zagrożenie porostów w Polsce. Monographiae Botanicae 91: 159-176.

Czarnota P., Glanc K., Nowak J. (2005): Materiały do bioty porostów Gorców ze zbiorów Herbarium Instituti Botanici Polskiej Akademii Nauk w Krakowie. Fragmenta Floristica et Geobotanica Polonica 12, 2: 327-370.

CzyżEwsKa K. (2003): Wprowadzenie. In: K. Czyżewska (ed). Zagrożenie porostów w Polsce. Monographiae Botanicae 91: 5-11.

CzyżEwSKA K., CIEŚLIŃSKI S. (2003): Czerwona lista porostów zagrożonych w Puszczy Białowieskiej. In: K. Czyżewska (ed.). Zagrożenie porostów w Polsce. Monographiae Botanicae 91: 107-120.

Diederich P., Ertz D., Stapper N., Sérusiaux E., Van den Broeck D., van den Boom P., Ries C. (2014): The lichens and lichenicolous fungi of Belgium, Luxembourg and northern France. URL: http:// www.lichenology.info [access: 9.07.2014].

FABISZEWSKi J. (1968 a): Porosty. In: J.B. Faliński (ed.). Park Narodowy w Puszczy Białowieskiej. Państwowe Wydawnictwo Rolne i Leśne, Warszawa: 87-90.

Fabiszewski J. (1968 b): Porosty Śnieżnika Kłodzkiego i Gór Bialskich. Monographiae Botanicae 26: $1-115$.

Fattynowicz W. (1992): The lichens of Western Pomerania (NW Poland). An ecogeographical study. Polish Botanical Studies 4: 1-182.

Fattynowicz W. (2003): The lichens, lichenicolous and allied fungi of Poland. An annotated checklist. Krytyczna lista porostów i grzybów naporostowych Polski. W. Szafer Institute of Botany, Polish Academy of Sciences, Kraków.
Glanc K. (1969): Flora porostów Arboretum w Gołuchowie. Prace Komisji Nauk Rolniczych i Komisji Nauk Leśnych PTPN 32: 23-38.

Golubkov V., Bohdan A., PopŁawska M. (2012): Nowe, rzadkie i interesujące gatunki porostów Białowieskiego Parku Narodowego. Parki Narodowe i Rezerwaty Przyrody $30(3,4): 15-26$.

Hafellner J., Türk R. (2001): Die lichenisierten Pilze Österreichs - eine Checkliste der bisher nachgewiesenen Arten mit Verbreitungsangaben. Stapfia 76: 1-167.

Holien H. (1989): The genus Bryoria Sect. Implexae in Norway. Lichenologist 21(3): 243-258.

KiszKA J. (1967 a): Porosty Beskidu Sądeckiego. Roczniki Naukowo-Dydaktyczne Wyższa Szkoła Pedagogiczna w Krakowie 28: 5-91.

KiszKA J. (1967 b): Porosty pasma Gubałówki. Fragmenta Floristica Geobotanica 13, 3: 419-446.

KIszKa K. (1985): Porosty Pogórza Spiskiego. Studia Ośrodka Dokumentacji Fizjograficznej 13: 213$-243$.

Kondratyuk S., Navrotskaya I., Khodosovtsev A., SoLONINA O. (1996): Checklist of Ukrainian lichens. Bocconea 6: 217-294.

Kossowska M. (2003): Czerwona lista porostów zagrożonych $\mathrm{w}$ polskiej części Sudetów In: K. Czyżewska (ed.). Zagrożenie porostów w Polsce. Monographiae Botanicae 91: 201-221.

Kossowska M., Szczepańska K., FatTynowicz W., Jando K., Kowalewska A., Dimos M. (2007): Species diversity of epiphytic lichens on monitored sample plots in the Karkonoski National Park (SW Poland). Parki Narodowe i Rezerwaty Przyrody 26, 1:3-16.

Kowalewska A., Kukwa M., Jando K. (2000): Nowe stanowiska rzadkich gatunków porostów w regionie gdańskim. Acta Botanica Cassubica 1: 127-134.

LišKa J., Palice Z., Slavíková S. (2008): Checklist and Red List of lichens of the Czech Republic. Preslia 80: 151-182.

Llimona X., Hladun N. L. (2001): Checklist of the lichens and lichenicolous fungi of the Iberian Peninsula and Balearic Islands. Bocconea 14: 1-581.

LuKÁč M. (2009): Occurrence and chemical diversity of the genus Bryoria in the Sučí Potok Valley, Veporské Vrchy Mountains (Central Slovakia). Central European Journal of Biology 4 (3): 417-421.

ŁubeK A. (2004): Porosty chronione w Świętokrzyskim Parku Narodowym i jego otulinie - stan obecny i kierunki zmian. Parki Narodowe i Rezerwaty Przyrody 23, 2: 179-191.

MotiejūNaité J. (1999): Checklist of lichens and allied fungi of Lithuania. Botanica Lithuanica 5 (3): 251-269.

Мотүка J. (1962): Porosty (Lichenes), 5.2. Usneaceae. Flora Polska. Rośliny zarodnikowe Polski i ziem ościennych. Państwowe Wydawnictwo Naukowe, Warszawa. 
Nascimbene J., Nimis P.L., Ravera S. (2012): Evaluating the conservation status of epiphytic lichens of Italy: A red list. Plant Biosystems 147, 4: 898-904.

NowaK J. (1998): Porosty Beskidów Wyspowego i Żywieckiego, Pasma Jałowca i Masywu Babiej Góry. Monographiae Botanicae 83: 1-131.

Nowak J., ToBolewski Z. (1975): Porosty polskie. Opisy i klucze do oznaczania porostów w Polsce dotychczas stwierdzonych lub prawdopodobnych. PWN, Warszawa-Kraków.

Orange A., James P.W., White FJ. (2001): Microchemical methods for the identification of lichens. British Lichen Society, London.

ORDYCZyŃSKA B. (1973): Porosty lasów nadleśnictwa Leżajsk w województwie rzeszowskim. Fragmenta Floristica Geobotanica 19, 1: 101-118.

RYDZAK J. (1961): Tree lichens in the forest communities of the Białowieża National Park. Annales Universitatis Mariae Curie-Skłodowska, Sectio C, 16: $17-47$.

RYDZAK J. (1969): Badania nad stanem ilościowym flory porostów nadrzewnych Puszczy Białowieskiej i Puszczy Ladzkiej. Annales Universitatis Mariae Curie-Skłodowska, Sectio C, 24: 65-72.

RydZAK J., SAŁATA B. (1970): Badania nad stanem ilościowym flory porostów nadrzewnych Puszczy Solskiej. Annales Universitatis Mariae Curie-Skłodowska, Sectio C, 25, 16: 159-165.

Santesson R., Moberg R., Nordin A., Tønsberg T., VitikAinen O. (2004): Lichen-forming and lichenicolous fungi of Fennoscandia. Uppsala, Museum of Evolution, Uppsala University.

SeAWARD M. (1994): Checklist of Yorkshire lichens. Proceedings Leeds Philosophical and Literary Society, Science Section 11: 85-120.

Søchting U., Alstrup V. (2002): Danish lichen checklist. Version 1. Botanical Institute, University of Copenhagen.

Sparrius L.B. (2003): Contribution to the lichen floras of the Białowieża Forest and the Biebrza Valley (Eastern Poland). Herzogia 16: 155-160.

SzCZEPAŃSKA K. (2006): Lichens of the 'Snieznik Klodzki' nature reserve in the Snieznik Massif (Sudety Mts). Parki Narodowe i Rezerwaty Przyrody $25,1: 3-16$.
SzCZEPAŃSKA K. (2008): Antropogeniczne przemiany bioty porostów Masywu Śnieżnika i Gór Bialskich. Acta Botanica Silesiaca Monographiae 4.

SZCZEPAŃSKa K., SzCZEPAŃSKI A. (2006): Lichens of the Bryoria genus in Karkonosze Mts. Fragmenta Floristica et Geobotanica Polonica 13(1): 191-195.

ŚliwA L. (1998): Antropogeniczne przemiany lichenoflory Beskidu Sądeckiego. Prace Botaniczne 31: 1-158.

TовоLEWsкi Z. (1965): Wykaz porostów dotychczas stwierdzonych w Polsce (wraz z bibliografią lichenologiczna). Poznańskie Towarzystwo Przyjaciół Nauk, Wydział Matematyczno-Przyrodniczy, Prace Komisji Biologicznej 24 (3): 1-62.

TÜRK R., HAFellneR J. (1999): Rote Liste gefährdeter Flechten (Lichenes) Österreichs. 2. Fassung. In: H. Niklfeld (ed.). Rote Listen gefährdeter Pflanzen Österreichs. 2. Auflage. Grüne Reihe des Bundesministeriums für Umwelt, Jugend und Familie, Band 10: 187-228.

Urbanavichus G., Andreev M. (2010): A checklist of lichen flora of Russia. Nauka, Sankt Petersburg.

VĚZDA A., LIšKA J. (1999): Katalog lišejníků České Republiky. Institute of Botany, Academy of Sciences of the Czech Republic, Průhonice.

WARMiŃSKA B. (1973): Materiały do flory porostów nadleśnictwa Kosobudy. Fragmenta Floristica Geobotanica 19, 1: 91-100.

WIRTH V. (1995): Flechten Baden-Württembergs. Teil 1 \& 2. Eugen Ulmer, Stuttgart: 182-189.

Woods R.G., Coppins B.J. (2012): A conservation evaluation of British lichens and lichenicolous fungi. Species Status 13. Joint Nature Conservation Committee, Peterborough. http://jncc.defra.gov. uk/pdf/Lichens_Web.pdf [access: 15.07.2014]

www.encyklopedia.puszcza-bialowieska.eu [access: 15.07.2014].

YazÝCÝ K., AsLan A. (2002): Additional lichen records from Rize Province. Turkish Journal of Botany 26: 181-193.

ZALEWSKa A. (2012): Ecology of lichens of the Puszcza Borecka Forest. W. Szafer Institute of Botany, Polish Academy of Sciences, Kraków. 